\title{
Putting Words into Action: Marketing Organic Products with Existing Brand Associations
}

\author{
Maren Vos ${ }^{1} \&$ Jos Bartels ${ }^{2}$ \\ ${ }^{1}$ Eindhoven University of Technology, Department of Industrial Engineering \& Innovation Sciences, Eindhoven, \\ The Netherlands \\ ${ }^{2}$ Tilburg University, Department of Communication and Cognition, Tilburg, The Netherlands \\ Correspondence: Jos Bartels, Department of Communication and Cognition, Tilburg University, Warandelaan 2, \\ 5037 AB, Tilburg, The Netherlands. Tel: 31-13-466-3584.
}

Received: March 13, $2018 \quad$ Accepted: April 26, $2018 \quad$ Online Published: May 7, 2018
doi:10.5539/ijms.v10n2p1
URL: https://doi.org/10.5539/ijms.v10n2p1

\begin{abstract}
As consumer interest in organic products continues to grow, brands are increasingly adding organic variants to their product lines. However, consumer evaluations of these actions are not straightforward and differ for brands with various associations or within different product contexts. Previous research has shown that products with credence attributes, such as organic products, are often judged by brand name and consumers' existing brand associations. The current study adds to previous work on brand equity and brand associations by explicitly considering the context and characteristics of these branded organic products. First, a pretest determined the existing brands' corporate social responsibility (CSR) and corporate ability (CA) associations. Next, an online experiment tested consumers' perceptions of brand equity, consumers' trust in the brands and consumers' purchase intentions, which were analyzed using a fully parallel, multiple-mediator process model with the experimental conditions as independent variables. The results show that brand equity increases most when a brand associated with both CA and CSR introduces an organic product. In addition, consumers trust this brand more compared to brands that are less strongly associated with CSR. Moreover, the intention to purchase organic products increases as brand equity increases, but the intention to purchase organic products does not increase as trust increases. Based on these results, we conclude that brands aiming to increase their value to positively affect consumers' purchase intentions of their organic products benefit most when they are highly associated with both CSR and CA.
\end{abstract}

Keywords: brand associations, brand equity, consumer perceptions, organic, purchase intention

\section{Introduction}

Today, consumers are increasingly considering the environmental and ethical aspects of products when making purchasing decisions (Andorfer \& Liebe, 2012; Bartels \& Onwezen, 2014; Carrington et al., 2014). All else being constant, consumers today are more likely to purchase from firms that engage in corporate social responsibility (CSR) actions than those that do not, especially when consumers perceive that the product aligns with their perceptions of the company (Sen \& Bhattacharya, 2001; Lee et al., 2012). In response to this heightened consumer awareness more brands are developing sustainable products and highlighting the sustainability of their products (Singh et al., 2012). Whereas some brands, such as The Body Shop, have engaged in CSR actions and have marketed sustainable products since their inception, nowadays traditional, mainstream brands, such as Garnier, also engage in CSR activities and market organic product lines (e.g., Garnier BIO ACTIVE - The Future is Organic).

Although mainstream brands are increasing their marketing efforts to promote sustainability and CSR in response to increased consumer awareness, several questionable company practices and scandals have been reported. These reports have resulted in consumers becoming increasingly cautious of "greenwashing" (Polonsky \& Rosenberger, 2001; Siano et al., 2017; Vlachos et al., 2009), which refers to the discrepancy between "talk" and "action" that occurs when brands use marketing to deceive consumers into believing that they prioritize CSR and/or sustainable products in order to capitalize on the potential benefits of having a "green" image (Elving, 2013; Siano et al., 2017). 
Consumers may be increasingly cautious of greenwashing because claims of sustainable products are difficult to validate (Pearson \& Henryks, 2008). For instance, organic product attributes are credence attributes, which means that consumers cannot immediately verify organic product attributes and must rely on the brand's claims. Therefore, consumers need more signals and cues to make judgments regarding the credibility of the claim (Perrini et al., 2010). Because the brand and its claims are the consumers' main source of information when evaluating organic products (Karstens \& Belz, 2006), consumers are forced to base their purchase decisions on the brand's value and reliability (Pearson \& Henryks, 2008; Belén del Río et al., 2001; Washburn et al., 2004). Therefore, the credibility and value that consumers assign to a brand are critical considerations when it comes to purchasing organic products.

According to previous research, consumer evaluations of a brand's products should be considered in the context of the brand's existing brand associations, that is, whether consumers associate the brand with CSR, operational excellence or innovativeness (Du et al., 2007). Two types of associations are essential for consumers when assessing a brand and its products: CA associations and CSR associations (Brown \& Dacin, 1997). CA associations refer to consumers' perceptions of the brand's production expertise, product quality and market leadership, whereas CSR associations concern the brand's environmental, ethical and socially responsible behavior (Berens et al., 2005; Brown \& Dacin, 1997; Kim, 2014; Sen \& Bhattacharya, 2001).

These CA and CSR associations significantly affect consumers' brand evaluations and, subsequently, consumers' intentions to purchase a product (Handelman \& Arnold, 1999; Kim et al., 2017). While several studies have discussed the various effects of CA and CSR associations on consumers' perceptions and behavior (e.g., Chen, 2001; Feldman \& Vasquez-Parraga, 2013), less is known about how existing CA or CSR associations determine consumers' perceptions and behavior when consumers assess the organic products offered by well-known brands. While we are aware that brands may benefit from strong CSR or CA associations, we still have few insights into how existing brand associations interact with organic product claims to influence consumers' perceptions and evaluations of products. Du et al. (2007) highlighted this gap in the literature by stating a need for research on the effects of CSR associations in more externally valid and competitive contexts.

Therefore, the current study aims to show how existing CA and CSR brand associations affect consumers' perceptions and evaluations of branded organic products and, subsequently, consumers' intention to purchase these products. We thus investigate the effects of brand associations on consumers' perceptions and purchase intentions in the context of introducing organic products by examining the role played by competitive positioning of established brands with varying degrees of CSR and CA associations (Du et al., 2007). This study is the first to compare the impact of existing CSR or CA associations for various brands on all the dimensions of brand equity (i.e., awareness, quality and loyalty) (Yoo et al., 2000) and trust (Vlachos et al., 2009) and to show how brand equity and trust mediate the effects of brand associations on consumers' purchase intentions, which predict responsible purchase behavior (Follows \& Jobber, 2000; Schuitema \& De Groot, 2015).

Our study compares existing, well-known brands that sell personal care products (PCPs), which is a product category in which consumers are often faced with credence attributes and that has a rapidly developing organic market. According to the Soil Association's 2018 Organic Market Report, sales of certified organic beauty products increased enormously over the past 10 years (Soil Association, 2018). Moreover, consumer interest in non-food organic products has grown (Organic Monitor, 2011), and a total market growth of approximately 16 billion dollars is expected by 2020, which reflects an annual growth rate for the organic PCP market of up to $10 \%$ across Europe, North America and the Asia Pacific regions (Grand View Research, 2014).

The paper proceeds as follows: First, we briefly describe the constructs of CA and CSR associations in relation to brand equity and trust. Next, we develop our conceptual framework based on existing theoretical approaches from the literature and derive testable, formal propositions. These propositions are subsequently tested in a field-experimental study. The results are reported and discussed. Finally, we conclude by discussing broader reflections on the findings and the limitations of the study and by providing suggestions for future research.

\section{Conceptual Background}

\subsection{CA and CSR Associations}

In a seminal paper on the role of brand associations in evaluating new products, Brown \& Dacin (1997) found that consumer choices are strongly influenced by different perceptions of the quality and achievements of the organization behind the brand. In addition to perceptions of expertise and quality (CA), a brand may be associated with a commitment to the environment and society (CSR). CSR and CA associations may coexist and may elicit different transactional and relational consumer responses (Du et al., 2007). Although various studies have shown how consumers' associations with a brand affected their evaluations of the brand, the results have 
differed across product types and in terms of how the CSR or CA messages were communicated. Building upon Brown \& Dacin (1997), several other papers on brand associations have shown that positive CA and/or CSR associations can result in positive product evaluations (Jayaraman et al., 2012; Madden et al., 2012). For example, Sen \& Bhattacharya (2001) found that consumers' judgments of brands can also be influenced by a trade-off between CA and CSR associations. This trade-off effect leads consumers to perceive that certain CSR characteristics diminish CA characteristics (Sen \& Bhattacharya, 2001). According to the authors, positive evaluations of CSR may thus lead to negative evaluations of CA, and both positive CA or CSR associations do not always result in positive brand evaluations. However, the same authors find in a later study that positive CSR brand awareness does increase consumers' CA beliefs in the context of real brands (Du et al., 2007). Therefore, results on the effects of existing CSR or CA associations on a brand's perceived value remain inconclusive because even when a brand is positively associated with both CSR and CA, this may have different effects on the consumer's evaluation of that brand and its products (Marín \& Ruiz, 2007).

Zhou et al. (2012) investigated the effects of CA associations, CSR associations and their possible interaction on consumers' responses to and evaluations of products. The results showed that both CA and CSR associations can have a positive effect on consumers' evaluations of low-involvement products. This builds on previous beliefs that positive CA and CSR associations may be complementary to one another, rather than acting as trade-offs. However, less is known regarding how positive associations affect brand equity in product contexts in which the consumer is required to assess the product's credence attributes based on the product's brand. This context potentially increases the importance of the brand evaluation. Because both CA and CSR branding and strategies are often employed to influence consumer perceptions, their effects on consumers within different contexts require closer examination. We therefore assume that consumers can and do associate well-known brands with both CA and CSR characteristics. The different ways in which these associations affect consumers' brand evaluations will be discussed next with our hypotheses, which are represented in Figure 1.

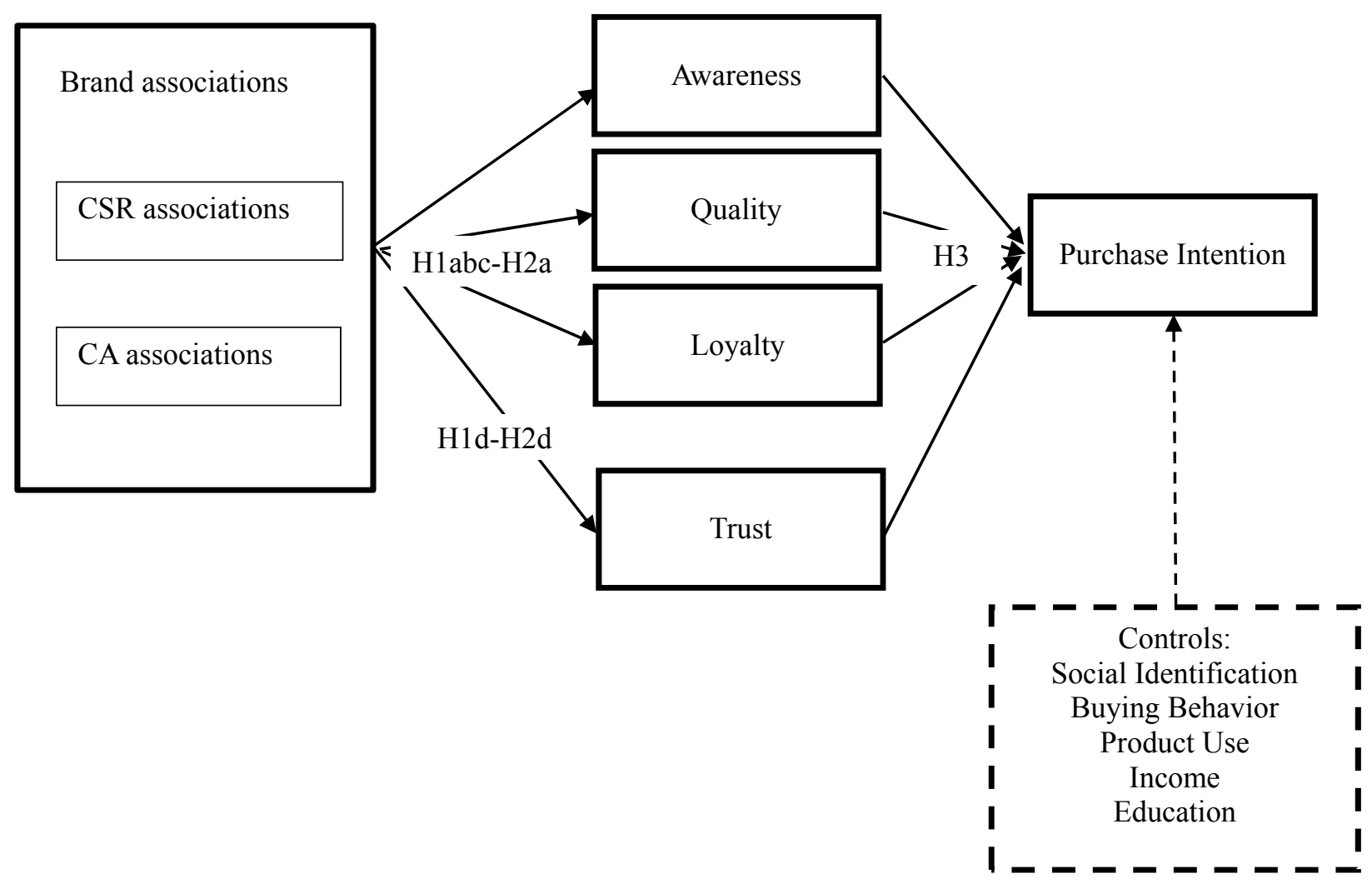

Figure 1. Conceptual Model

\subsection{CSR and Brand Equity for Organic Products}

Research has shown that positive CSR associations can lead to positive brand evaluations (Hsu, 2012; Marín \& Ruiz, 2007; Perera \& Chaminda, 2013). The current study defines these brand evaluations as brand equity, or the 
incremental value added to a product by a brand. Brand equity consists of the consumer's awareness of, perceived quality of and loyalty to the brand (Yoo et al., 2000). Brand equity is shaped through associations with, and knowledge of, the brand (Yoo \& Donthu, 2001; Yoo et al., 2000). For example, brands that are strongly associated with CSR can also be associated with high-quality products (Hoeffler \& Keller, 2002) and can increase consumer loyalty to and positive behavior toward the brand (Bhattacharya \& Sen, 2003; Du et al., 2007). However, other authors state that positive brand associations in general increase consumer loyalty (Chaudhuri \& Holbrook, 2001), which means that consumer loyalty is not solely due to positive CSR associations.

CSR associations may affect brand equity when the characteristics of certain products align with CSR characteristics. That is, consumers seem to prefer new products when brand associations fit the new product's characteristics (Broniarczyk \& Alba, 1994). Castaldo et al. (2009) showed a positive relationship between CSR associations and consumer reactions to organic products. This could give brands that are strongly associated with CSR an advantage over competitors when these brands are introducing organic products (Castaldo et al., 2009).

An explanation of the effect of CSR associations on consumer loyalty may be that the product relates to these CSR associations, which then strengthens the consumer's positive brand perceptions. Indeed, several studies have shown the positive effects of a fit between brand associations and product characteristics (Gupta \& Sen, 2013; Madrigal, 2000). Thus, when an ethical brand introduces an organic product, it may have an additional positive influence on the brand's environmentally friendly image (Chen, 2010; Jayaraman et al., 2012). By contrast, when a brand that is not associated with ethical or sustainable characteristics introduces an organic product, this may create opposing, negative effects compared to its competitors. We therefore propose the following:

H1: When confronted with an organic product, consumers will have higher levels of a) awareness of, b) perceived quality of and c) loyalty to a brand with high CSR associations than to its competitors.

In addition to the added value of the brand, consumers' attitudes and purchase decisions are partly shaped by the consumers' trust in the brand (Krystallis \& Chryssohoidis, 2005). Brand associations influence consumers' responses in a similar way across multiple product categories (Singh et al., 2012). Consumers partly assess the credence attributes of, for example, organic products based on their trust in a brand (Castaldo et al., 2009). Consumers' trust in a brand increases when an ethical brand introduces an organic or sustainable product, because this is consistent with the consumers' expectations of the brand (Castaldo et al., 2009; Perrini et al., 2010). For example, there is a strong, positive relationship between CSR associations and consumers' trust in brands that have incorporated organic food products into their product offerings (Perrini et al., 2010). We thus propose the following:

H1d: When confronted with an organic product, consumers will have higher levels of trust in a brand with high CSR associations than in its competitors.

\subsection{CA and Brand Equity for Organic Products}

While Brown \& Dacin (1997) showed that, for existing brands, consumers' CA associations could also lead to negative evaluations of new products, the authors did not provide a clear explanation of why these contrasting effects may exist. One explanation could be that consumers' reactions to products are influenced by the perceived fit between product features and brand associations (Madrigal, 2000; Torelli et al., 2011). When a product's characteristics do not fit the consumers' brand associations, consumers may prefer other brands (Broniarczyk \& Alba, 1994). Other research showed that perceived "corporate hypocrisy," or the belief that a firm claims to be something that it is not, damages consumers' attitudes toward firms by negatively affecting their CSR beliefs and their attitudes toward the firm (Marín et al., 2016; Wagner et al., 2009).

For organic products, consumers' reactions to the products are also partially influenced by the degree to which the consumers believe the product fits their associations with the brand (Madrigal, 2000). Because organic products are often perceived as more expensive than non-organic products (Krystallis \& Chryssohoidis, 2005), the product characteristics may conflict with specific CA associations, such as efficiency and cost reduction (Jayaraman et al, 2012; Madrigal, 2000). For example, consumer goods firms' informal systems may strongly promote sustainability, while their formal systems may continue to adopt a traditional focus on financial performance (Epstein et al., 2015). Consequently, knowledgeable consumers may believe that when an organization wants to behave in a socially responsible manner, this diminishes the organization's performance in the CA domain (Sen \& Bhattacharya, 2001) because this socially responsible behavior does not fit certain CA attributes, such as efficiency. In addition, brands that are associated with CA are also associated with quality, which may conflict with the perception that green products are of lower quality than non-green products. Recent research has shown that most consumers place much importance on the basic ability of environmentally 
sustainable products to fulfill basic "functional" consumption goals (Ramirez et al., 2015). Indeed, a barrier to the purchasing of green products is concern regarding product performance (Pickett-Baker \& Ozaki, 2008). So, when there is no perceived fit between the product's performance or quality features and consumer (CA) brand associations, this could result in a preference for other (competing) brands (Klink \& Smith, 2001; Maoz \& Tybout, 2002). This implies that the perceived lack of fit by the consumer may diminish the brand's added value. We therefore propose the following hypothesis:

H2: When confronted with an organic product, consumers will have lower levels of a) awareness of, b) perceived quality of and c) loyalty to a brand with high CA associations than to its competitors.

Although organic products positively affect consumer trust, this effect is generally exclusively found within an ethical or sustainable context due to the brand's sustainable image (Chen, 2010). When product characteristics influence consumer's trust in a brand, introducing an organic product by a brand not associated with CSR could be perceived as inconsistent (Madrigal, 2000). According to Vlachos et al. (2009), when consumers perceive firms' sustainable initiatives to be mainly strategic or profit driven, this will negatively affect consumers' trust in the firms due to heightened consumer suspicion and public cynicism. Consumers may be suspicious of "greenwashing" (Polonsky \& Rosenberger, 2001; Siano et al., 2017; Vlachos et al., 2009), which occurs when brands use marketing to deceive consumers into believing that they prioritize CSR and/or market sustainable products, in an attempt to capitalize on the potential benefits of having a "green" image (Elving, 2013; Siano et al., 2017). Therefore, when consumers associate a certain brand with CA, this will be perceived as inconsistent with the brand's image. We thus propose the following:

H2d: When confronted with an organic product, consumers will have lower levels of trust in a brand with high CA associations than in its competitors.

\subsection{Brand Equity, Trust and Purchase Intentions}

The types of associations consumers have with a brand influence their preferences for that brand's products in relation to those of its competitors (Yoo et al., 2000). This specific preference can be determined by measuring the consumer's purchase intention. When deciding to purchase organic products, consumers must rely on the brand and its claims as their main source of information (Karstens \& Belz, 2006) and must base their purchase on the brand's value and reliability (Pearson \& Henryks, 2008; Belén del Río et al., 2001; Washburn et al., 2004). Therefore, the credibility and value that consumers assign to a brand are critical considerations when it comes to purchasing organic products. Current research on the effects of these existing CSR or CA associations on the evaluation of a brand's products reports inconclusive results, which may be caused by the different ways in which a brand that is associated with both CSR and CA affects consumer perceptions (Marín \& Ruiz, 2007). We argue that CSR and CA associations may affect consumers' intentions to purchase organic products through different routes. Specifically, we propose that these effects are mediated by brand awareness, quality, loyalty and trust. Indeed, previous research shows that purchase intention is determined by consumers' attitudes toward and perceptions of the brand (Bartels \& Hoogendam, 2011). For example, both loyalty alone and brand equity may positively affect purchase intentions (Chen, 2010; Sen \& Bhattacharya, 2001; Yoo et al., 2000). In addition to loyalty, more trust in the brand can also increase consumers' purchase intentions (Singh et al., 2012). Especially for sustainable products, trust is an important predictor of purchase intentions, as consumers need to judge the brand's product claims and characteristics based on the brand's credibility (Castaldo et al., 2009; Perrini et al., 2010). We thus assume that brand equity and trust mediate the effect of brand associations on purchase intentions and that higher levels of brand equity and trust will increase intentions to purchase organic products.

H3: Consumers' a) awareness, b) perceptions of quality, c) loyalty and d) trust mediate the relationship between brand associations and intentions to purchase branded organic products.

\section{Method}

\subsection{Pretest}

To test the effects of CA and CSR associations on brand equity, we first conducted a pretest. In this pretest, we included brands with the highest market share in the Dutch PCP market (Nielsen Market Analytics, April 2013), as the impact of product attributes was more defined for these well-known brands (Schuitema \& De Groot, 2015) The included brands were NIVEA, L'Oréal, Dove, Sanex, Palmolive and Rituals. The respondents in the pretest were presented with all six brands and were asked if they were familiar with the brand (the respondents could reply yes/no to this question). When the respondents answered "yes" to the familiarity question, they were then prompted to answer questions about their CA and CSR associations with the specific brand (cf. Brown \& Dacin, 1997). The pretest questionnaire was completed by 39 respondents in a within-subjects design. The results of the 
pretest showed that all the brands scored significantly higher on CA associations than on CSR associations (see Table 1). Therefore, a brand that scored higher on CSR associations relative to CA associations could not be selected. To test the hypotheses, we therefore decided to select 1) a brand that scored relatively high on CA associations but not on CSR, 2) a brand that scored relatively higher on CSR associations compared to the other brands and lower on CA associations than brands 1 and 3) a brand that scored relatively lower on CA associations but higher on CSR associations than brand 1. Based on an ANOVA, the following brands were selected: 1) L'Oréal, 2) Rituals and 3) Palmolive. L'Oréal scored the highest on CA compared to all the other brands, and its CSR associations were significantly lower than those of the other brands. Rituals scored significantly higher on CSR than L'Oréal and Palmolive and higher on CA than Palmolive. Palmolive scored lower on CA than most of the other brands, higher on CSR than L'Oréal and lower on CSR than Rituals.

Table 1. Pretest ANOVA results

\begin{tabular}{|c|c|c|c|c|c|c|c|}
\hline \multirow[t]{2}{*}{ Brand } & \multicolumn{2}{|l|}{$C A$} & \multicolumn{2}{|l|}{ CSR } & \multirow[t]{2}{*}{ Compared brand } & \multicolumn{2}{|c|}{ Mean Difference } \\
\hline & Mean & $\alpha$ & Mean & $\alpha$ & & $C A t$ & $\operatorname{CSR} t$ \\
\hline \multirow[t]{5}{*}{ 1. L’Oréal } & $3.81 * *$ & .88 & 2.27 & .91 & 2. Rituals & .66 & $-5.30 * *$ \\
\hline & & & & & 3. Palmolive & $5.43^{* *}$ & $-2.61^{*}$ \\
\hline & & & & & Dove & $2.32 *$ & $-2.18^{*}$ \\
\hline & & & & & Nivea & 1.55 & $-3.79 * *$ \\
\hline & & & & & Sanex & $5.78 * *$ & $-2.42 *$ \\
\hline \multirow[t]{5}{*}{ 2. Rituals } & $3.74 * *$ & .89 & 3.15 & .84 & 1. L'Oréal & -.66 & $5.30 * *$ \\
\hline & & & & & 3. Palmolive & $4.26^{* *}$ & $4.48^{* *}$ \\
\hline & & & & & Dove & .87 & $2.31 *$ \\
\hline & & & & & Nivea & .51 & 1.47 \\
\hline & & & & & Sanex & $4.63 * *$ & $2.59 *$ \\
\hline \multirow[t]{5}{*}{ 3. Palmolive } & $2.97 * *$ & .88 & 2.57 & .93 & 1. L'Oréal & $-5.43^{* *}$ & $2.61 *$ \\
\hline & & & & & 2. Rituals & $-4.26 * *$ & $-4.48^{* *}$ \\
\hline & & & & & Dove & $-3.87 * *$ & -.94 \\
\hline & & & & & Nivea & $-5.21 * *$ & -1.77 \\
\hline & & & & & Sanex & .30 & -.46 \\
\hline
\end{tabular}

Note. $* \mathrm{p}<.05, * * \mathrm{p}<.01$, two-sided tests.

\subsection{Respondents}

To test hypotheses 1 to 5 , a convenience sample was used. A total of 165 respondents participated in the online experiment. We conducted manipulation checks to determine whether the respondents had bought shampoo in the past and whether the respondents had recognized the correct brand. Three respondents could not identify the brand they had been exposed to, so these respondents were not included in the study. After the removal of incomplete questionnaires and participants who had only answered "7" on both positively and negatively formulated items, the results of 121 respondents were used for further analyses. The respondents were $39 \%$ male and $61 \%$ female and were (mostly) between 20 and 30 years old. Moreover, $30 \%$ of the respondents had a bachelor's degree, and $58 \%$ had a master's degree. For $60 \%$ of the respondents, their net income per month was between $\$ 1000$ and $\$ 2000$.

\subsection{Stimulus Material}

We decided not to distinguish between men and women. We therefore chose shampoo as a gender-neutral PCP, as it seems that shampoos are used equally by both male and female consumers (Hall et al., 2011). Because product claims appeal to men and women differently (Schlessinger, 2007), we selected a neutral shampoo "for regular hair." Moreover, Padel \& Foster (2005) concluded that even if products make an organic claim, most consumers find it difficult to interpret this claim. We therefore incorporated the " $100 \%$ natural" claim and the "organic" claim on the product packages of the presented brands. Finally, for all three brand packages, we used a green shampoo bottle, as green is most often associated with organic or natural products (Browne et al., 2000). Every shampoo bottle featured the brand logo of L'Oréal, Palmolive or Rituals. The respondents were randomly assigned to one of the three conditions in a between-subjects design: L'Oréal $(N=42)$, Palmolive $(N=42)$ or Rituals $(N=37)$.

\subsection{Mediating Variables}

Brand equity was measured on a seven-point Likert scale using the following dimensions: Awareness, Quality and Loyalty, as proposed by Yoo et al. (2000). The three-item scales were reliable for every condition: Awareness 
(Cronbach's $\alpha_{\mathrm{L}}=.91 ; \alpha_{\mathrm{P}}=.79$ and $\alpha_{\mathrm{R}}=.94$ ), Quality (Cronbach's $\alpha_{\mathrm{L}}=.69 ; \alpha_{\mathrm{P}}=.65$ and $\alpha_{\mathrm{R}}=.82$ ) and Loyalty (Cronbach's $\alpha_{\mathrm{L}}=.90 ; \alpha_{\mathrm{P}}=.89$ and $\alpha_{\mathrm{R}}=.95$ ). Some of the items included the following: "I can recognize X among other competing brands", "I consider products made by X to be of high quality" and "I consider myself to be loyal to X." To test whether the three dimensions of brand equity were perceived to be different, we conducted a CFA in AMOS 20.0. The results showed that the three-dimensional model $(\chi 2 / \mathrm{df}=2.12 ; \mathrm{CFI}=.97$; TLI $=.95$; RMSEA $=.10 ;$ SRMR $=.06)$ provided a better fit than the one-dimensional model $(\chi 2 / \mathrm{df}=16.22 ; \mathrm{CFI}=.47$; TLI $=.29$; RMSEA $=.37$; SRMR $=.21)$. Although the RMSEA did not entirely meet the standard criterion of $<.08$, we decided to continue with the three-dimensional model following Yoo et al. (2000), as Hu and Bentler (1999) state that it is often sufficient to rely on the SRMR and one of the remaining indexes for model fit comparisons. In addition to brand equity, we measured trust using items on an existing seven-point Likert scale, which was derived from Chaudhuri and Holbrook's (2001) study (Cronbach's $\alpha=.93$ ).

\subsection{Dependent Variables}

Purchase intention was measured using three items derived from Kim and Chung's (2011) research on consumers' purchase behavior of organic PCPs. The participants answered questions on a seven-point Likert scale, in which $1=$ completely disagree and 7 = completely agree. The statements included the following: "I am planning to buy this organic shampoo soon," and "It is highly likely that I will buy this organic shampoo." Based on a reliability analysis (Cronbach's $\alpha=.97$ ), we composed one scale from these items.

\subsection{Control Variables}

Social identification was incorporated as a control variable, because based on Social Identity Theory (Tajfel, 1978), Bartels \& Hoogendam (2011) state that the identification of consumers with a social group of "organic consumers" may result in the consumer developing a positive attitude toward the convictions and behaviors of that group, which will increase the likelihood that the consumer will engage in more sustainable behaviors and increase the consumer's intention to purchase organic products in general. We measured social identification using three items on a seven-point Likert scale, which was derived from Leach et al.'s study (2008) (Cronbach's $\alpha=.97)$. In addition, purchase behavior of organic products and product (shampoo) use were measured based on a scale by De Pelsmacker \& Janssens (2007), as the degree to which a respondent bought and used similar products may have been determining factors in explaining the respondents' purchase intentions. The participants indicated how often they bought or used organic products or shampoo. The frequency of purchasing organic products resulted in the buying behavior scale (Cronbach's $\alpha=.77$ ). A similar scale developed by De Pelsmacker and Janssens (2007) was used to assess how often respondents used shampoo (Cronbach's $\alpha=.72$ ). Income and education level were also considered as controls in the analysis, as we found that there was no equal spread of these characteristics among our respondents, which may have affected our results.

\section{Results}

To test hypotheses 1 to 3 , we used process modelling in order to test the fully parallel, multiple-mediator model across the three conditions (Hayes, 2012). The estimation of the direct and indirect effects in our model required four models to predict our mediators, $M$, from our three conditions, $X$, and a single model of purchase intention that included all four mediators plus the three conditions as predictors. We used Hayes process model 4, which allowed for the inclusion of multi-categorical, independent variables and for a comparison of the effects of brand associations across the three experimental conditions using planned contrasts. Planned contrasts compared the effects across the three conditions, in which we decided to assign Palmolive as the baseline condition, as this brand had the lowest CSR and CA associations among the brands.

We tested our hypotheses according to the levels of brand awareness, brand equity, brand loyalty and trust. Therefore, we discuss the results of H1-H2a, H1-H2b, H1-H2c and H1-H2d jointly. First, we tested the effect of the three conditions on awareness, including the four control variables $\left(F(1,113)=3.34, p<.01, \mathrm{R}^{2}=.17\right)$. The analysis showed a significant difference across conditions in terms of awareness $(\mathrm{b}=5.54, p<0.001,95 \%$ confidence interval [3.39-7.69]). Planned contrasts showed that L'Oréal did not score significantly different from Palmolive $(\mathrm{b}=.38, p>0.05,95 \%$ confidence interval [-.27-1.03]), but Rituals did score significantly higher than both L'Oréal and Palmolive ( $\mathrm{b}=1.32, p<0.001,95 \%$ confidence interval [.65-1.99]). Therefore, H1a was confirmed, and H2a was partially confirmed. Specifically, the consumers reported higher levels of awareness when confronted with an organic product of a brand with high CSR (H1a) but did not report lower levels of awareness when confronted with an organic product of a brand with high CA (H2a).

Second, we tested the differences in quality across the three conditions, including the four control variables $(F(7$, $\left.113)=1.62, p>.05, \mathrm{R}^{2}=.09\right)$. A significant effect on quality was found $(\mathrm{b}=5.63, p<0.001,95 \%$ confidence interval [4.14-7.13]). Planned contrasts showed that L'Oréal did not score significantly different on quality than 
Palmolive $(\mathrm{b}=.21, p>0.05,95 \%$ confidence interval [-.24-66]), but Rituals scored significantly higher than both L'Oréal and Palmolive $(\mathrm{b}=.7, p<0.01,95 \%$ confidence interval [.24-1.16]). Therefore, H1b was confirmed, and $\mathrm{H} 2 \mathrm{~b}$ was partially confirmed. Specifically, the consumers reported higher levels of quality when confronted with an organic product of a brand with high CSR (H1b) but did not report lower levels of quality when confronted with an organic product of a brand with high CA $(\mathrm{H} 2 \mathrm{~b})$.

Third, we tested the difference in loyalty across the three conditions, including the four control variables $(\mathrm{F}(7$, $\left.113)=2.56, \mathrm{p}<.05, \mathrm{R}^{2}=.14\right)$. The analysis showed a significant effect of the conditions in terms of loyalty $(\mathrm{b}=$ $2.91, p<0.01,95 \%$ confidence interval [.91-4.9]). Planned contrasts showed that L'Oréal scored significantly higher than Palmolive on loyalty $(\mathrm{b}=.63, p<0.05,95 \%$ confidence interval [.03-1.23]), and Rituals scored significantly higher than both Palmolive and L'Oréal $(b=.7, p<0.05,95 \%$ confidence interval [.09-1.32]). Therefore, H1c was confirmed, but H3c was not confirmed and even showed an opposite effect. Specifically, the consumers reported the highest levels of loyalty when confronted with an organic product of a brand with high CSR (H1c) but also reported higher levels of loyalty to a brand with high CA, contrary to our expectations $(\mathrm{H} 2 \mathrm{c})$.

Fourth, we tested the differences in trust across the three conditions, including the four control variables $(F(7$, $\left.113)=1.24, p>.05, \mathrm{R}^{2}=.07\right)$. The analysis showed a significant difference across the three conditions in terms of trust ( $\mathrm{b}=5.26, p<0.001,95 \%$ confidence interval [3.59-6.93]). Planned contrasts showed that L'Oréal did not score significantly different from Palmolive $(\mathrm{b}=.18, p>0.05,95 \%$ confidence interval [-.32-.69]), but Rituals did score significantly higher than both L'Oréal and Palmolive $(\mathrm{b}=.65, p<0.05,95 \%$ confidence interval [.13-1.16]). Therefore, H1d was confirmed, and H2d was partially confirmed. Specifically, the consumers reported higher levels of trust when confronted with an organic product of a brand with high CSR (H1d) but did not report lower levels of trust when confronted with an organic product of a brand with high CA (H2d).

Finally, the fully parallel mediated model $\left(F(11,109)=10.81, p>.001, \mathrm{R}^{2}=.52\right)$ represented a substantial improvement from the non-mediated total effect model $\left(F(7,113)=4.85, p>.05, \mathrm{R}^{2}=.23\right)$, as the former showed that the effect on purchase intention for the organic products from the three brands was mediated by brand equity and trust (H3). Furthermore, the results showed that both quality $(\mathrm{b}=.28, p<0.05,95 \%$ confidence interval $[.0005-.57])$ and loyalty $(\mathrm{b}=.59, p<0.001,95 \%$ confidence interval $[.4-.78])$ significantly increased purchase intention. However, no significant effects were found for awareness $(b=.02, p>.05,95 \%$ confidence interval $[-.15-.19])$ and trust $(\mathrm{b}=-.09, p>0.05,95 \%$ confidence interval $[-.34-.16])$. Lastly, we found a significant effect of social identification $(\mathrm{b}=.27, p<0.001,95 \%$ confidence interval [.13-.42]), which suggested that social identification was an important predictor of consumers' intentions to purchase organic products in general.

\section{Conclusions}

Based on the results, we conclude the following: First, the more positively a consumer associates a brand with both CA and CSR associations, the higher consumers' awareness, perceptions of quality and loyalty will be when confronted with an organic product from that brand. Therefore, a brand with more positive CA and CSR associations has a higher brand equity compared to a brand with relatively weaker CA and CSR associations, or mainly positive CA associations. In contrast to our expectations, high CA brand associations do not decrease brand equity compared to a brand with low CA associations. The pretest showed that Rituals was associated more with both CA and CSR than Palmolive, which had relatively low CA and CSR associations. This was in line with research by Du et al. (2007), who found that brands associated with "intrinsic" CSR motives were positively evaluated on the CA domain. This aligned with our findings for the Rituals brand, which originally positioned itself as a CSR brand. In contrast to our expectations, L'Oréal scored higher than Palmolive on loyalty; this finding aligned with that of Chaudhuri and Holbrook (2001). The overall lower brand equity for brands with relatively weaker associations implied that the total set of brand associations was more important than either high CA or CSR associations. Therefore, a striking result of the current study was that strong, positive brand associations in general determined brand loyalty although only the combination of both strong CA and CSR associations truly increased brand equity for consumers confronted with organic products.

Second, we found that the brand with the most positive associations also scored highest on trust, while the brand strongly associated with only CA (and not CSR) did not score lower on trust than the brand with low CA and average CSR associations. We thus found no evidence that consumers do not trust brands due to a perceived misfit between the organic product and their CA brand associations. However, we did find that consumers evaluate strong CSR brands more positively when confronted with organic products.

Third, while the difference in purchase intention caused by the manipulation was mediated by brand equity and 
trust, we found that quality perceptions and loyalty increased purchase intentions, while awareness and trust did not. This provided strong evidence for our claim that the value of a brand predicts consumers' intentions to purchase organic products.

In short, brands may be associated with both CA and CSR characteristics. Although the possible benefits of introducing an organic product are higher for brands currently associated with CSR, other brands may still benefit, as the effects of CSR associations and organic product introductions seem complementary. The results of our experiment add to our current understanding of consumer-brand associations and brand equity in the context of organic product attributes. Confronted with an organic product, the consumers reported higher awareness of, perceived quality of, loyalty to and trust in the brand with the strongest CSR associations among the different brands.

The current study extends previous knowledge on CA and CSR associations in several ways. First, several researchers have studied the effects of CA and CSR associations on consumer perceptions (Berens et al., 2005; Brown \& Dacin, 1997; David et al., 2005; Feldman \& Vasquez-Parraga, 2013; Sen \& Bhattacharya, 2001). However, until now, none of these studies empirically considered the effects of CA and CSR brand associations on brand equity in a product context. In line with Zhou et al. (2012) and Chen (2010), the results of the current study indicate that consumers can and do associate brands with both CA and CSR, as the total set of positive associations can ultimately increase positive consumer-brand valuation and the intention to purchase organic products. We therefore add to the understanding of the effects of brand associations by showing how these effects are more defined when considering the context and attributes of the branded product.

Second, this study adds to the existing literature on sustainable product marketing, as the results show how consumers evaluate products through brand associations in a sustainable context. More specifically, we extend previous research on sustainable products and their impact on consumer-brand perceptions. Previous work focuses primarily on corporate CA or CSR messages (Biehal \& Sheinin, 2007), on the role of organic labels in consumer behavior (Bauer et al., 2013) or, more recently, on how the attributes of green products positively influence purchase intentions (Schuitema \& De Groot, 2015). We thus posit that brands wanting to increase their brand equity based on positive CSR associations may prefer to introduce organic products instead of just communicating CSR. This finding supports research by Pickett-Baker and Ozaki (2008), who state that consumer attitudes are more favorable toward environmentally friendly brands. These positive perceptions resulting from an organic product introduction are even more important in light of developments showing that consumers are becoming increasingly skeptical about companies' sustainability initiatives. In this context, Polonsky and Rosenberger (2001) already argued that when consumers suspect greenwashing, this could lead to boycott or even financial loss. More recently, Vries et al. (2013) found that people easily suspect greenwashing when companies invest in environmental measures. Thus, introducing a new organic product, rather than only communicating CSR, may lead consumers to perceive the brand as more valuable than its competitors.

Third, the current study contributes to filling the gap between the growing market for organic products and the scarcity of scientific research on (environmentally sustainable) PCPs (Kim \& Chung, 2011). Although previous research found that consumers' product perceptions differ among product category contexts (Ratneshwar \& Shocker, 1991), until now only one study has been conducted on PCPs (Kim \& Chung, 2011). Because different product characteristics have been shown to drive purchase probabilities (Inman et al., 2009) and to affect purchase behavior (Van Trijp et al., 1996), it is important to study the effects of brand associations on brand equity in various product contexts. This study contributes to this line of research by showing that consumers evaluate well-known PCP brands more positively depending on the characteristics of the PCP (e.g., whether the $\mathrm{PCP}$ is organic).

\subsection{Marketing Implications}

The results of this study have some implications for marketing managers. When a brand manager of a CSR brand is looking to increase brand equity, he/she may consider introducing an organic product. However, the brand does not necessarily only need a specific CSR reputation or image. More importantly, the brand should communicate its innovative characteristics as a market leader as well as its sense of responsibility toward the environment and society. Combining CA with CSR characteristics seems to be the best strategy for attracting more consumers than one's competitors. Although brands should constantly aim to remain competitive, the overall effects of sustainability initiatives will be much lower for brands with a weak reputation in general than for brands that already evoke multiple positive associations. In addition to the degree to which consumers associate a brand with CSR or CA, our results suggest that PCP brands should introduce an organic variant when looking to increase the consumers' trust in their brand. However, higher trust will not directly result in higher 
purchase intentions. Marketing managers aiming to increase the consumers' trust in a sustainable brand should thus consider adding a sustainable PCP to their product lines.

\section{Limitations and Future Research}

The current study has some limitations. First, based on the pretest, no clear distinction could be made between brands with either high CSR or CA associations. Although we tried to overcome this by adding an additional brand with lower CA associations, isolating the effects was difficult with real-world brands and thus should be attempted in future research. We decided to choose well-known PCP brands with the highest market shares, and research has confirmed that the impact of green attributes is more defined when self-serving motives (i.e., for familiar or well-known brands) are fulfilled as compared to situations where consumers are unfamiliar with the brand (Schuitema \& De Groot, 2015). Although this study aimed to identify the real-world effects of marketing organic products for well-known brands, future research may want to consider lesser-known PCP brands. Brands that are less familiar compared to the brands we used in our manipulations may have less-established associations. This may make it easier for consumers to identify a brand as being more CSR or CA-oriented, as consumers' associations would be less influenced by the brand's real-world marketing initiatives. If brand associations were more defined, stronger effects on brand equity could be found.

Second, we combined a CSR or CA test with the product quality dimension of brand equity. Because the definition of CA partly consists of "quality dimensions of the firm's internal processes" (Brown \& Dacin, 1997), there may have been some overlap (Du et al., 2007). Although one may expect that this would, in general, increase high-CA brands' perceived quality, we decided to use the full brand equity scale, which aligned with previous research by Berens et al. (2005), who also considered product and brand evaluations to be different. The results of our experiment showed that this seemed to be the case, as we found significant differences between both high-CA brands. Future research may nonetheless compare various measures and types of consumer-brand evaluations and how these are affected by CSR and CA associations. For example, Kim et al., (2001) already found that consumers' identification with a brand had a direct effect on positive word-of-mouth. Moreover, Carrol and Ahuvia (2006) stated the importance of brand love, which was positively related to brand loyalty and behavioral outcomes, such as word-of-mouth. Future research could thus consider comparing the effects of brand identification and brand love for brands with different CSR and CA associations.

Third, while we did not include a second manipulation check for CSR and CA associations in the main experiment, we did compare the demographic characteristics of the participants in the pretest with the participants in the main study and did not find any significant differences. Moreover, participants' demographics did not significantly influence the dependent variables in the study. However, future experimental research could include an instructional manipulation check to increase statistical power (Oppenheimer et al., 2009).

Finally, we did not explicitly consider consumers' personal attributes. The success of an brand's strategy of positioning itself on CSR or CA attributes may depend on the product category and consumers' personal values (Kim et al., 2017). CSR initiatives can be assessed differently for different types of consumers (Mohr et al., 2001), depending on the context of peer groups (Öberseder et al., 2011). While we included social identification as a control variable, the results of the experiment clearly indicated the importance of considering social identification in a sustainable consumption context. In addition, we did not control for consumers' skepticism and perceptions of greenwashing, which may have decreased brand equity. Thus, future studies may want to control for personal attributes and factors when considering brand associations and brand equity in a product context.

\section{Conclusion}

In sum, this research shows that a brand deciding to introduce a new organic product should be aware of the strong positive associations of their current brand as well as a variety of product characteristics. Ultimately, investing in improving multiple positive associations instead of focusing on either CSR or CA is likely the most competitive strategy in terms of increasing brand equity and purchase intentions for organic products. However, an increase in brand equity is highest when a brand already associated with CSR introduces an organic product. We therefore argue that while positive associations in general are important, brands are able to truly increase their brand's equity when they put put words into action by both promoting sustainability and CSR values and introducing organic products.

\section{References}

Andorfer, V. A., \& Liebe, U. (2012). Research on fair trade consumption-A review. Journal of Business Ethics, 106(4), 415-435. http://dx.doi.org/10.1007/s10551-011-1008-5 
Bartels, J., \& Hoogendam, K. (2011). The role of social identity and attitudes toward sustainability brands in buying behaviors for organic products. Journal of Brand Management, 18(9), 697-708. http://dx.doi.org/10.1057/bm.2011.3

Bartels, J., \& Onwezen M. C. (2014). Consumers' willingness to buy products with environmental and ethical claims: the roles of social representations and social identity. International Journal of Consumer Studies 38(1), 82-89. http://dx.doi.org/10.1111/ijcs.12067

Bauer, H. H., Heinrich, D., \& Schäfer, D. B. (2013). The effects of organic labels on global, local, and private brands: More hype than substance? Journal of Business Research, 66(8), 1035-1043. http://dx.doi.org/10.1016/j.jbusres.2011.12.028

Belén del Río, A., Vazquez, R., \& Iglesias, V. (2001). The effects of brand associations on consumer response. Journal of Consumer Marketing, 18(5), 410-425. http://dx.doi.org/10.1108/07363760110398808

Berens, G., van Riel, C. B., \& van Bruggen, G. H. (2005). Corporate associations and consumer product responses: The moderating role of corporate brand dominance. Journal of Marketing, 69(3), 35-48. http://dx.doi.org/10.1509/jmkg.69.3.35.66357

Bhattacharya, C. B., \& Sen, S. (2003). Consumer-company identification: A framework for understanding consumers' relationships with companies. Journal of Marketing, 67(2), 76-88. https://doi.org/10.1509/jmkg.67.2.76.18609

Biehal, G. J., \& Sheinin, D. A. (2007). The influence of corporate messages on the product portfolio. Journal of Marketing, 71(2), 12-25. http://dx.doi.org/10.1509/jmkg.71.2.12

Broniarczyk, S. M., \& Alba, J. W. (1994). The importance of the brand in brand extension. Journal of Marketing Research, 31(2), 214-228. http://dx.doi.org/10.2307/3152195

Brown, T. J., \& Dacin, P. A. (1997). The company and the product: Corporate associations and consumer product responses. Journal of Marketing, 61(1), 68-84. http://dx.doi.org/10.2307/1252190

Browne, A. W., Harris, P. J., Hofny-Collins, A. H., Pasiecznik, N., \& Wallace, R. R. (2000). Organic production and ethical trade: definition, practice and links. Food Policy, 25(1), 69-89. http://dx.doi.org/10.1016/S0306-9192(99)00075-5

Carrington, M. J., Neville, B. A., \& Whitwell, G. J. (2014). Lost in translation: Exploring the ethical consumer intention-behavior gap. Journal of Business Research, 67(1), 2759-2767. http://dx.doi.org/10.1016/j.jbusres.2012.09.022

Carroll, B. A., \& Ahuvia, A. C. (2006). Some antecedents and outcomes of brand love. Marketing Letters, 17(2), 79-89. http://dx.doi.org/10.1007/s11002-006-4219-2

Castaldo, S., Perrini, F., Misani, N., \& Tencati, A. (2009). The missing link between corporate social responsibility and consumer trust: The case of fair trade products. Journal of Business Ethics, 84(1), 1-15. http://dx.doi.org/10.1007/s10551-008-9669-4

Chaudhuri, A., \& Holbrook, M. B. (2001). The chain of effects from brand trust and brand affect to brand performance: the role of brand loyalty. Journal of Marketing, 65(2), 81-93. https://doi.org/10.1509/jmkg.65.2.81.18255

Chen, Y. S. (2010). The drivers of green brand equity: Green brand image, green satisfaction, and green trust. Journal of Business Ethics, 93(2), 307-319. http://dx.doi.org/10.1007/s10551-009-0223-9

Cheng-Hsui Chen, A. (2001). Using free association to examine the relationship between the characteristics of brand associations and brand equity. Journal of Product and Brand Management, 10(7), 439-451. http://dx.doi.org/10.1108/10610420110410559

David, P., Kline, S., \& Dai, Y. (2005). Corporate social responsibility practices, corporate identity, and purchase intention: A dual-process model. Journal of Public Relations Research, 17(3), 291-313. http://dx.doi.org/10.1207/s1532754xjprr1703_4

De Pelsmacker, P., \& Janssens, W. (2007). A model for fair trade buying behavior: The role of perceived quantity and quality of information and of product-specific attitudes. Journal of Business Ethics, 75(4), 361-380. http://dx.doi.org/10.1007/s10551-006-9259-2

Du, S., Bhattacharya, C. B., \& Sen, S. (2007). Reaping relational rewards from corporate social responsibility: The role of competitive positioning. International Journal of Research in Marketing, 24(3), 224-241. 
https://doi.org/10.1111/j.1468-2370.2009.00276.x

Elving, W. J. (2013). Scepticism and corporate social responsibility communications: The influence of fit and $\begin{array}{llll}\text { reputation. Journal of Marketing } & \text { Communications, }\end{array}$ https://doi.org/10.1080/13527266.2011.631569

Epstein, M. J., Buhovac, A. R., \& Yuthas, K. (2015). Managing social, environmental and financial performance simultaneously. Long Range Planning, 48(1), 35-45. http://dx.doi.org/10.1016/j.lrp.2012.11.001

Feldman, M. P., \& Vasquez-Parraga, A. Z. (2013). Consumer social responses to CSR initiatives versus corporate abilities. Journal of Consumer Marketing, 30(2), 100-111. http://dx.doi.org/10.1108/07363761311304915

Follows, S. B., \& Jobber, D. (2000). Environmentally responsible purchase behaviour: a test of a consumer model. European Journal of Marketing, 34(5/6), 723-746. http://dx.doi.org/10.1108/03090560010322009

Grand Review Research. (2014). Organic Personal Care Market Analysis by Product (Skin Care, Hair Care, Oral Care, Cosmetics) and Segment Forecasts To 2020.

Gupta, R., \& Sen, S. (2013). The effect of evolving resource synergy beliefs on the intentions-behavior discrepancy in ethical consumption. Journal of Consumer Psychology, 23(1), 114-121. https://doi.org/10.1016/j.jcps.2012.07.004

Hall, B., Steiling, W., Safford, B., Coroama, M., Tozer, S., Firmani, C., \& Gibney, M. (2011). European consumer exposure to cosmetic products, a framework for conducting population exposure assessments Part 2. Food and Chemical Toxicology, 49(2), 408-422. http://dx.doi.org/10.1016/j.fct.2010.11.016

Handelman, J. M., \& Arnold, S. J. (1999). The role of marketing actions with a social dimension: Appeals to the institutional environment. Journal of Marketing, 63(3), 33-48. http://dx.doi.org/10.2307/1251774

Hayes, A. F. (2012). PROCESS: A versatile computational tool for observed variable mediation, moderation, and conditional process modeling [White paper]. Retrieved from http://www.afhayes.com/public/process2012.pdf

Hoeffler, S., \& Keller, K. L. (2002). Building brand equity through corporate societal marketing. Journal of Public Policy \& Marketing, 21(1). 78-89. https://doi.org/10.1509/jppm.21.1.78.17600

Hu, L. T., \& Bentler, P. M. (1999). Cutoff criteria for fit indexes in covariance structure analysis: Conventional criteria versus new alternatives. Structural Equation Modeling: A Multidisciplinary Journal, 6(1), 1-55. http://dx.doi.org/10.1080/10705519909540118

Hsu, K. T. (2012). The Advertising Effects of Corporate Social Responsibility on Corporate Reputation and Brand Equity: Evidence from the Life Insurance Industry in Taiwan. Journal of Business Ethics, 109(2), 189-201. http://dx.doi.org/10.1007/s10551-011-1118-0

Inman, J. J., Winer, R. S., \& Ferraro, R. (2009). The interplay among category characteristics, customer characteristics, and customer activities on in-store decision making. Journal of Marketing, 73(5), 19-29. http://dx.doi.org/10.1509/jmkg.73.5.19

Jayaraman, V., Singh, R., \& Anandnarayan, A. (2012). Impact of sustainable manufacturing practices on consumer perception and revenue growth: an emerging economy perspective. International Journal of Production Research, 50(5), 1395-1410. http://dx.doi.org/10.1080/00207543.2011.571939

Karstens, B., \& Belz, F. M. (2006). Information asymmetries, labels and trust in the German food market: A critical analysis based on the economics of information. International Journal of Advertising, 25(2), 189-211. http://dx.doi.org/10.1080/02650487.2006.11072962

Kim, H., \& Chung, J. E. (2011). Consumer purchase intention for organic personal care products. Journal of Consumer Marketing, 28(1), 40-47. http://dx.doi.org/10.1108/07363761111101930

Kim, S. (2014). What's worse in times of product-harm crisis? Negative corporate ability or negative CSR reputation? Journal of Business Ethics, 123(1), 157-170. http://dx.doi.org/10.1007/s10551-013-1808-x

Kim, C. K., Han, D., \& Park, S. B. (2001). The effect of brand personality and brand identification on brand loyalty: Applying the theory of social identification. Japanese Psychological Research, 43(4), 195-206. http://dx.doi.org/10.1111/1468-5884.00177

Kim, Y., Park, H., \& Kim, J. K. (2017). Corporate association strategies and consumer responses: The relative effectiveness of CA versus CSR communication strategy by industry type. Journal of Marketing Communications. 1-24. http://dx.doi.org/10.1080/13527266.2017.1393766 
Klink, R. R., \& Smith, D. C. (2001). Threats to the external validity of brand extension research. Journal of Marketing Research, 38(3), 326-335. http://dx.doi.org/10.1509/jmkr.38.3.326.18864

Krystallis, A., \& Chryssohoidis, G. (2005). Consumers' willingness to pay for organic food: Factors that affect it and variation per organic product type. British Food Journal, 107(5), 320-343. http://dx.doi.org/10.1108/00070700510596901

Leach, C. W., Van Zomeren, M., Zebel, S., Vliek, M. L., Pennekamp, S. F., Doosje, B., Ouwerkerk, J. W., \& Spears, R., 2008. Group-level self-definition and self-investment: a hierarchical (multicomponent) model of in-group identification. Journal of Personality and Social Psychology, 95(1), 144-165. http://dx.doi.org/10.1037/0022-3514.95.1.144

Lee, E. M., Park, S. Y., Rapert, M. I., \& Newman, C. L. (2012). Does perceived consumer fit matter in corporate social responsibility issues? Journal of Business Research, 65(11), 1558-1564. http://dx.doi.org/10.1016/j.jbusres.2011.02.040

Madden, T. J., Roth, M. S., \& Dillon, W. R. (2012). Global product quality and corporate social responsibility perceptions: a cross-national study of halo effects. Journal of International Marketing, 20(1), 42-57. http://dx.doi.org/0.1509/jim.11.0016

Madrigal, R. (2000). The influence of social alliances with sports teams on intentions to purchase corporate $\begin{array}{lllll}\text { sponsors' products. Journal of } & \text { Advertising, } & \text { 29(4), }\end{array}$ http://dx.doi.org/10.1080/00913367.2000.10673621

Maoz, E., \& Tybout, A. M. (2002). The moderating role of involvement and differentiation in the evaluation of brand extensions. Journal of Consumer psychology, 12(2), 119-131. https://doi.org/10.1207/S15327663JCP1202_05

Marín, L., \& Ruiz, S. (2007). I need you too! Corporate identity attractiveness for consumers and the role of social responsibility. Journal of Business Ethics, 71(3), 245-260. http://dx.doi.org/10.1007/s10551-006-9137-y

Marín, L., Cuestas, P. J., \& Román, S. (2016). Determinants of Consumer Attributions of Corporate Social Responsibility. Journal of Business Ethics, 138(2), 247-260. http://dx.doi.org/10.1007/s10551-015-2578-4

Mohr, L. A., Webb, D. J., \& Harris, K. E. (2001). Do consumers expect companies to be socially responsible? The impact of corporate social responsibility on buying behavior. Journal of Consumer Affairs, 35(1), 45-7. http://dx.doi.org/10.1111/j.1745-6606.2001.tb00102.x

Nielsen Market Analytics. Retrieved from http://www.nielsen.com/apac/en/solutions/sales-measurement.html.

Öberseder, M., Schlegelmilch, B. B., \& Gruber, V. (2011). Why don't consumers care about CSR?: A qualitative study exploring the role of CSR in consumption decisions. Journal of Business Ethics, 104(4), 449-460. http://dx.doi.org/10.1007/s10551-011-0925-7

Oppenheimer, D. M., Meyvis, T., \& Davidenko, N. (2009). Instructional manipulation checks: Detecting satisficing to increase statistical power. Journal of Experimental Social Psychology, 45(4), 867-872. https://doi.org/10.1016/j.jesp.2009.03.009

Organic Monitor. (2011). The Global Market for Natural and Organic Cosmetics. London, UK.

Padel, S., \& Foster, C. (2005). Exploring the gap between attitudes and behaviour: Understanding why consumers buy or do not buy organic food. British Food Journal, 107(8), 606-625. http://dx.doi.org/10.1108/00070700510611002

Pearson, D., \& Henryks, J. (2008). Marketing organic products: Exploring some of the pervasive issues. Journal of Food Products Marketing, 14(4), 95-108. http://dx.doi.org/10.1080/10454440801986421

Perera, L. C. R., \& Chaminda, J. W. D. (2013). Corporate social responsibility and product evaluation: The moderating role of brand familiarity. Corporate Social Responsibility and Environmental Management, 20(4), 245-256. http://dx.doi.org/10.1002/csr.1297

Perrini, F., Castaldo, S., Misani, N., \& Tencati, A. (2010). The impact of corporate social responsibility associations on trust in organic products marketed by mainstream retailers: a study of Italian consumers. Business Strategy and the Environment, 19(8), 512-526. http://dx.doi.org/10.1002/bse.660

Pickett-Baker, J., \& Ozaki, R. (2008). Pro-environmental products: marketing influence on consumer purchase decision. Journal of Consumer Marketing, 25(5), 281-293. http://dx.doi.org/10.1108/07363760810890516 
Polonsky, M. J., \& Rosenberger, P. J. (2001). Reevaluating green marketing: a strategic approach. Business Horizons, 44(5), 21-30. http://dx.doi.org/10.1016/S0007-6813(01)80057-4

Ramirez, E., Jiménez, F. R., \& Gau, R. (2015). Concrete and abstract goals associated with the consumption of environmentally sustainable products. European Journal of Marketing, 49(9/10), 1645-1665. http://dx.doi.org/10.1108/EJM-08-2012-0483

Ratneshwar, S., \& Shocker, A. D. (1991). Substitution in use and the role of usage context in product category structures. Journal of Marketing Research, 28(3), 281-295. http://dx.doi.org/

Schuitema, G., \& Groot, J. I. (2015). Green consumerism: The influence of product attributes and values on purchasing intentions. Journal of Consumer Behaviour, 14(1), 57-69. http://dx.doi.org/10.2307/3172864

Schlessinger, J. (2007). Skin care for men and its marketing. Dermatologic Therapy, 20(6), 452-456. https://doi.org/10.1111/j.1529-8019.2007.00161.x

Sen, S., \& Bhattacharya, C. B. (2001). Does doing good always lead to doing better? Consumer reactions to corporate social responsibility. Journal of Marketing Research, 38(2), 225-243. http://dx.doi.org/10.1509/jmkr.38.2.225.18838

Siano, A., Vollero, A., Conte, F., \& Amabile, S. (2017). "More than words": Expanding the taxonomy of greenwashing after the Volkswagen scandal. Journal of Business Research, 71, 27-37. https://doi.org/10.1016/j.jbusres.2016.11.002

Singh, J. J., Iglesias, O., \& Batista-Foguet, J. M. (2012). Does having an ethical brand matter? The influence of consumer perceived ethicality on trust, affect and loyalty. Journal of Business Ethics, 111(4), 541-549. http://dx.doi.org/10.1007/s10551-012-1216-7

Soil Association. (2018). Retrieved from https://www.soilassociation.org/organicmarketreport/

Tajfel, H. (1978). Social categorisation, social identity and social comparison. In H. Tajfel (Ed.), Differentiation Between Social Groups: Studies in the Social Psychology of Inter Group Relations (pp. 61-76). London: Academic Press.

Torelli, C. J., Monga, A. B., \& Kaikati, A. M. (2012). Doing poorly by doing good: Corporate social responsibility and brand concepts. Journal of Consumer Research, 38(5), 948-963. http://dx.doi.org/10.1086/660851

Van Trijp, H. C., Hoyer, W. D., \& Inman, J. J. (1996). Why switch? Product category: level explanations for true variety-seeking behavior. Journal of Marketing Research, 33(3), 281-292. http://dx.doi.org/10.2307/3152125

Vries, G., Terwel, B. W., Ellemers, N., \& Daamen, D. D. (2015). Sustainability or profitability? How communicated motives for environmental policy affect public perceptions of corporate greenwashing. Corporate Social Responsibility and Environmental Management, 22(3), 142-154. https://doi.org/10.1002/csr.1327

Vlachos, P. A., Tsamakos, A., Vrechopoulos, A. P., \& Avramidis, P. K. (2009). Corporate social responsibility: attributions, loyalty, and the mediating role of trust. Journal of the Academy of Marketing Science, 37(2), 170-180. http://dx.doi.org/10.1007/s11747-008-0117-x

Wagner, T., Lutz, R. J., \& Weitz, B. A. (2009). Corporate hypocrisy: Overcoming the threat of inconsistent corporate social responsibility perceptions. Journal of Marketing, 73(6), 77-91. http://dx.doi.org/10.1509/jmkg.73.6.77

Washburn, J. H., Till, B. D., \& Priluck, R. (2004). Brand alliance and customer - based brand equity effects. Psychology and Marketing, 21(7), 487-508. https://doi.org/10.1002/mar.20016

Yoo, B., \& Donthu, N. (2001). Developing and validating a multidimensional consumer-based brand equity scale. Journal of Business Research, 52(1), 1-14. https://doi.org/10.1016/S0148-2963(99)00098-3

Yoo, B., Donthu, N., \& Lee, S. (2000). An examination of selected marketing mix elements and brand equity. Journal of the Academy of Marketing Science, 28(2), 195-211. http://dx.doi.org/10.1177/0092070300282002

Zhou, Y., Poon, P., \& Huang, G. (2012). Corporate ability and corporate social responsibility in a developing country: the role of product involvement. Journal of Global Marketing, 25(1), 45-56. http://dx.doi.org/10.1080/08911762.2012.697385 


\section{Copyrights}

Copyright for this article is retained by the author(s), with first publication rights granted to the journal.

This is an open-access article distributed under the terms and conditions of the Creative Commons Attribution license (http://creativecommons.org/licenses/by/4.0/). 